\title{
CHARACTERISTIC OF APOPTOSIS AND EXPRESSION OF GENES-RELATED APOPTOSIS (c-myc, $c$-erb AND $c$-fos ONCOGENE) IN HeLa CELL LINES AFTER EXPOSURE BY NEEM (Azadirachta indica A.Juss)
}

\author{
Dessy Arisanty ${ }^{1}$, Zolkapli Eshak ${ }^{3}$, Fauziah Othman ${ }^{1,3}$, Asmah Rahmat ${ }^{1,2}$, Abdah M.D. Akim ${ }^{1}$, \\ Nurmawaty ${ }^{1}$, Suhaida. M. Jalil ${ }^{1}$ \\ ${ }^{1}$ Department of Biomedical Science, University of Putra Malaysia \\ ${ }^{2}$ Department of Nutrition \& Health Science, Faculty of Medicine and Health Sciences, \\ University of Putra Malaysia \\ ${ }^{3}$ Institute of Bioscience, University of Putra Malaysia
}

\begin{abstract}
Azadirachta indica A. Juss is a medicinal plant commonly known as neem. The effect of neem leaves extract on cervical cancer cells, however, has never been studied. Due to the lack of information, this study was conducted to determine the effect of neem leaves extract on cervical cancer (HeLa) cell growth. In vitro cytotoxicity effect of ethanolic neem extract indicated the presence of cytotoxicity activity of the extract against $\mathrm{HeLa}$ cells with $\mathrm{IC}_{50}$ of $30.0 \mu \mathrm{g} / \mathrm{mL}$. The morphological changes under confocal laser scanning microscope (CLSM) on HeLa cells were cell shrinkage and membrane blebbing. There were also cells with condensed nucleus and few cells have fragmented nucleus, and finally formed apoptotic body. Control cells showed a clear cytoplasm and centrally placed nucleus and no cells exhibited any apoptotic features. Appearance of apoptotic cells under scanning electron microscope (SEM) are indentations, blebs and hole on cell surface and disintegration of cell. The controls remained morphologically normal. Apoptotic features of the cells are widely seen with longer incubation time while 24 hours incubation time, it is scarcely seen. The RT-PCR product showed that the $c$-erb gene expression was expressed in both treated and untreated HeLa cells. Contrary, the the $c-m y c$ and $c$-fos oncogenes on HeLa cells which exposed to $A$. indica EtOH extract were significantly decreased. Thus, the results from this study strongly suggest that the ethanolic extract of $A$. indica may contain bioactive compound(s) that caused cervical cancer cells, HeLa cell death by apoptosis mechanism and lead to succession of discovering new alternative treatment for cervical cancer.
\end{abstract}

Keywords : cytotoxic, apoptosis genes, oncogenes, neem

\section{INTRODUCTION}

Cancer is a complex diseases, and many of cellular genes have now been implicated in the development of the malignancy. These can be inherited or acquired somatically as a result of spontaneous or environmentally inflicted error during DNA replication ${ }^{[1]}$. Cervical cancer is the most common gynaecological malignancy, and the second most prevalent cause of death among female cancer patients in Malaysia ${ }^{[2]}$. With the number of cases diagnosed increasing over the years, the importance of early detection and treatment is becoming ever more apparent.
Azadirachta indica is a plant from Meliaceae family. Azadirachta indica, the neem tree is native plant in India and Burma. Scientific research has confirmed many of the traditional uses of neem and offers many exciting new therapeutic applications. Local name of neem in the many locations ; "Nim" in Bengali, "Vepa" in Tamil, "Nimba" in Sanskrit, "Veppu" in malyali , "Margosa tree" in English, "Mimba" in Indonesia and "Semambu" in Malaysia ${ }^{[3]}$. Many explorations to find herbs and other forms of natural medicines that can be used in complementary cancer treatment. 
In medicine, it is used for the treatment of a variety of human illnesses and diseases. Neem (Azadirachta indica) was known as base formulated pesticides in agriculture, as antiinflammatory, anti-pyretic and antitumor property ${ }^{[4]}$. Furthermore, Neem was known to have cytotoxic effect, anti bacterial, antifungal, hypoglycemic effect, genotoxicity effect ${ }^{[5]}$, cytogenesis toxicity effect ${ }^{[6]}$ and for beauty industry is used in natural cosmetics and organic skin care product. Recent study reported that Neem leaf extract has a potential as an anticancer agent in breast cancer ${ }^{[7,8]}$.

More complex bioassay of active components will be monitored using interactions with relevant cell lines, including apoptosis and oncogene expression/suppression. Apoptosis, or programmed cell death, is a physiologic mechanism responsible for the elimination of unwanted cells at various stages of development, injury, and repair ${ }^{[9]}$ and genetically controlled process whereby the cell actively participates in its own destruction in response to environmental, developmental cues or extracellular trigger ${ }^{[10]}$.

One of suitable methods is TUNEL (terminal deoxyribonucleotide transferase-mediated dUTP-X nick end-labeling) staining are standard techniques for detection of apoptosis $^{[11]}$ This method is novel and simple method will permit the determination of indices of sensitivity and specificity for apoptosis detection ${ }^{[12]}$. Other than TUNEL staining, the best studied to confirm structural changing during apoptosis by using electron miscroscope.

In recent years, there has been interest in the biology of c-myc. The c-myc proto-oncogene is frequently overexpressed in human cancer and its function is as central regulator of cell proliferation as well as its role in cell cycle regulation, especially the relevancy of c-myc related to apoptosis in cancer focus ${ }^{[13,14]}$.

Oncogene HER2/C-erbB-2 is expressed at low levels in a variety of healthy human adult epithelial cells ${ }^{[15]}$. However, the overexpression of HER-2/c-erbB-2 genes at least $30 \%$ of primary human mammary adenocarcinomas and indicates a poor response to chemotherapy ${ }^{[16]}$.
Other oncogenes, the human c-fos protooncogene plays an essential role in the growth of mammalian cells. It is representative of a class of genes termed immediate early genes, which activation correlates with the exit of cells from the quiescent, or $\mathrm{G}_{0}$ state, and entry into cell cycle ${ }^{[17]}$.

However, there has been no scientific report to test ability of neem extract to kill HeLa cancer cells. Therefore, in this particular study, the focus has aimed at evaluating the ethanolic neem extract cytotoxic property, determine the possible mechanism of apoptosis elicited by the neem extract on HeLa cell lines (cervical cancer cells) and anticancer properties of Azadirachta indica, A.Juss (neem) through the supression of cancer-causing genes such as cmyc, c-erb and c-fos, thus providing a mechanistic target for future research and treatment approaches.

\section{MATERIAL AND METHODS}

\section{Cell Culture}

HeLa, cervical cancer cell lines were maintained with RPMI-1640 supplemented with $10 \%$ Fetal Calf Serum and 1\% (v/v) penicillin streptomycin at $37^{\circ} \mathrm{C}$ in humidified atmosphere at $5 \%(\mathrm{v} / \mathrm{v}) \mathrm{CO}_{2}$ in air incubator. RPMI-1640, fetal calf serum and penicillin streptomycin were obtained from GIBCO BRL, Rockville. Mp (USA).

\section{The Preparation of Ethanolic Extract of Neem Leaves.}

Neem leaves were collected from UPM botanical garden. One hundred gram of dried leaves powder was subjected to solvent extraction $200 \mathrm{~mL} 80 \%$ ethanol in borosilicate glass bottle and kept overnight at room temperature. This step was repeated for three consequent days. Finally, the extract were combined and left to evaporate using rotary evaporator. Then freeze dried at $-80^{\circ} \mathrm{C}$ for 24 hours before different concentration of neem extract could be obtained.

\section{Micro Tetrazolium (MTT) Assay}

After 72 hours MCF-7 cells exposed to 
ethanolic extract of $A$. indica (neem), $20 \mu \mathrm{L}$ (5 $\mathrm{mg} / \mathrm{mL}$ PBS) of MTT solution were added into each well and incubated at $37^{\circ} \mathrm{C}$ for 4 hours. After 4 hours, most of the media from each well wee remove before adding $100 \mu \mathrm{L}$ of $100 \%$ DMSO into the wells. They were mixed thoroughly to dissolve the purple crystal and kept for 30 minutes at room temperature. Finally, the absorbance was read at wavelength of $550 \mathrm{~nm}$ using ELISA reader.

\section{Microscopy Analysis of Apoptosis}

TUNEL Assay

Analysis of apoptotic cell was conducted using TUNEL assay. The cells were exposed to ethanolic extract of $A$. indica with $\mathrm{IC}_{50}$ concentration in Labtek chamber slide for 24, 48 and 72 hours followed with TUNEL staining (PROMEGA). Viewing was done using Confocal laser scanning microscopy.

\section{Quantification of Apoptotic Cells}

Quantification of the apoptotic cells was done by using a confocal laser scanning microscope (CLSM). Statistical analysis was carried out using Student $t$-test (SPSS for windows version 13). The differences were only considered statistically significant if $p<0.05$.

\section{SEM (Scanning Electron Microscopy)}

Apoptotic features were observed under the scanning electron microscope (SEM). Treated cells were grown and fix on coverslips. Then, the specimen was mounted by sticking onto the stub using double sided tape or colloidal silver before the specimen was coated with palladium gold in a sputter coater (Polaron E 5100) and viewed under the scanning electron microscope (JSEM 6400).

Lesion Scoring for Scanning Electron Microscope

Lesson scoring was did base on the appearance of apoptosis identified on the cell. Lesson scoring did on the surface morphology appearance and rate from $0-3$ base on to the criteria below (Table 1).

\section{Treatment of Cells for Oncogene Expression}

For the study of the expression of c-myc, c-fos and c-erb oncogene. Ten mililiter of cell suspension were pipetted into a $75 \mathrm{~cm}^{2}$ flask (Nunc, Denmark) and three flasks were used for each type of treatment. The amounts of cells were $1 \times 10^{5}$. Flasks were incubated for 24 hours in a $5 \% \mathrm{CO}_{2}$ incubator (Sanyo, Japan) at $37^{\circ} \mathrm{O}$ The $\mathrm{IC}_{50}$ of the compounds were added and one flask with no compound was used as a control. The flasks and the chamber slides were incubated again in a $50 \% \quad \mathrm{CO}_{2}$ incubator (Sanyo, Japan) at $37^{\circ} \mathrm{C}$ for 96 hours. Then the cells in the flask were harvested by using a rubber scraper and collected by centrifugation at $1000 \mathrm{rpm}$ for 1 minute.

\section{Extraction mRNA}

In this study, Perfect RNA, Eukaryotic, Mini Kit (Eppendorf) was used to extract RNA from the cell lines. After 72 hours post treatment, the cells were washed twice with $500 \mathrm{uL}$ PBS. Next, $500 \mu \mathrm{L}$ trypsin-EDTA was added and incubated for 2-3 minutes for detachment of the cells. To extract total RNA, $350 \mu \mathrm{L}$ Lysis Solution (Appendix D2) was added and mixed by vigorous vortexing and pipetting up and down several times. The homogenized cells were then transferred to a $1.5 \mathrm{~mL}$ eppendorf tube and spinned for 5 minutes at $12,000 \mathrm{~g}$. Following this, the supernatant was transferred to a fresh $1.5 \mathrm{~mL}$ tube carefully. $350 \mu \mathrm{L}$ of $70 \%$ ethanol was added to the lysate and mixed completely by very gentle repeated inversion.

Table 1. Lesion Scores for Scanning Electron Microscope

\begin{tabular}{cc}
\hline Score & Characteristic \\
\hline 0 & Smooth plasma membrane \\
1 & $\begin{array}{c}\text { Dentations and/or blebs on } \\
\text { cell surface }\end{array}$ \\
2 & Hole on cell surface \\
3 & Disintegration of cell \\
\hline
\end{tabular}


After that, $200 \mu \mathrm{L}$ of Perfect RNA Binding Matrix Solution was added to the lysate and mixed gently by repeated inversion. Then, a perfect RNA Mini Spin Column was placed into a fresh $1.5 \mathrm{~mL}$ microcentrifuge tube and carefully the lysate/Binding matrix mixture was pipetted into the Spin Column. The Spin Column was then centrifuged for 30-60 seconds at $12,000 \times \mathrm{g}$.

Filtrate from the collection tube was discarded and the Spin Column was placed back into the same microcentrifuge tube. The RNA were washed by adding $700 \mu \mathrm{L}$ Wash Solution 1 and centrifuged for 15-30 seconds at 12,000 $\times$ g. The filtrate was then discarded and the Spin Column was placed back to the same collection tube and centrifuged for 30 seconds to remove any residual Wash Solution 1 from Spin Column. RNA were washed by adding $500 \mu \mathrm{L}$ of Diluted wash solution II and centrifuged for 15 seconds at 12,000 to 16,000 $\times \mathrm{g}$ for twice. The Spin Column was then transferred to an RNase-free collection tube and $50 \mu \mathrm{L}$ of Molecular Biology Grade Water was added to the Binding Matrix to elute the RNA. The Spin Column Assembly was vortexed for 1 second to completely moisten the entire dried binding matrix before being incubated for 5 minutes at $50^{\circ} \mathrm{C}$ C. The Spin Column was vortexed again for 5 seconds and immediately centrifuged for 2 minutes at $12,000 \times \mathrm{g}$. The RNA obtained was used immediately or stored at $80^{\circ} \mathrm{C}$ for further usage.

\section{Reverse Transcriptase-Polymerase Chain Reaction (RT-PCR) c-erb and c-fos}

In order to extract c-myc, c-erb and c-fos from the HeLa cell lines, Mbiotech product was used. To make a $25 \mu \mathrm{L}$ complete reaction, 5 $\mu \mathrm{L}$ of total RNA was added with $2 \mu \mathrm{L}$ of reverse and forward primer, $1.5 \mu \mathrm{L}$ of reverse and forward housekeeping, $0.5 \mu \mathrm{L}$ RNase free water and topped up with $12.5 \mu \mathrm{L} 5 \mathrm{x}$ mastermix. The complete reaction was heated at $65^{\circ} \mathrm{C}$ for 5 minutes and quickly chilled on ice. Incubation was done at $42^{\circ} \mathrm{C}$ for 60 minutes. The RNA were denatured at $96^{\circ} \mathrm{C}$ for 3 minutes and preceded with PCR cycle for 35 times. The PCR conditions were $94^{\circ} \mathrm{C}$ for 1 minute, $55^{\circ} \mathrm{C}$ for 1 minute and $72^{\circ} \mathrm{C}$ for 1 minute. The RT-PCR amplication products were analyzed with a $1.5 \%$ agarose gel.

\section{Agarose Gel Electrophoresis}

Agarose (0.6 g) was filled in an Erlenmeyer flask and $40 \mathrm{~mL}$ TBE-buffer was added. The flask was placed into a microwave oven and heated at maximum energy level until the agarose was completely dissolved. Then, the solution was poured into the prepared electrophoresis chamber and placed on the gel comb. After the gel hardened, the tape was removed from the open ends of the gel platform and the gel comb was withdrawn. pocket. Additionally, a DNA molecular weight marker was prepared by mixing it with 1-3 ug of purified DNA was mixed with the loading buffer and filled into the loading loading buffer. A TBE buffer was added to cover the gel at a depth of about $3 \mathrm{~mm} 7.5 \mu \mathrm{L}$ of samples were loaded carefully into the sample pockets using a micropipet. Elecetrophoresis was then performed until the Bromophenol Blue dye from the loading buffer migrated to the end of the platform. The visualization of the DNA was done by placing the gel onto a UV light source and the image was snapped.

\section{RESULTS \& DISCUSSIONS}

This study demonstrates the morphological changes in the cell and cell surface of HeLa cell lines (cervical cancer cells) treated with Azadirachta indica (neem) leaves extract. Microculture/Microtitration Tetrazolium (MTT) assay was done initially to determine the cytotoxic effect of crude ethanolic extract of neem leaves on cervical cancer cell lines. Then, a graph of percentage cell viability versus different concentration was plotted.

The MTT assay is a routine cytotoxicity assay used to determine the cell proliferation rate and conversely, when metabolic events that leads to apoptosis or necrosis, the reduction in cell viability. Figure 1 illustrated the percentage of viable cell versus neem leaves extract at different concentration. The $\mathrm{IC}_{50}$ value was determined through the graph. The value of $\mathrm{IC}_{50}$ of the extract was $30 \mu \mathrm{g} / \mathrm{mL}$. Plant extract with the $\mathrm{IC}_{50}$ value of equal or less than 100 $\mu \mathrm{g} / \mathrm{mL}$ is considered to be active. If the value 
is more than $100 \mu \mathrm{g} / \mathrm{mL}$ the extract is considered inactive. Thus in this study, the crude ethanolic neem extract showed to be active in inducing cytotoxic activity. From previous study, neem leaves extract was proven in inducing apoptosis in MCF-7 breast cancer cell lines ${ }^{[7,8,18,19]}$.

Apoptosis is characterized by accompanying morphological changes cell death. Two main hallmarks of apoptosis are the condensation and the fragmentation of chromatin ${ }^{[20]}$. Other the characteristic of apoptosis are cell shrinkage and loss of microvilli. Sequence of morphological of apoptosis can be seen by using microscopy analysis. The cleavage of chromosomal DNA that can be detected by TUNEL (Figure 2) and viewed under confocal laser scanning microscope (CLSM). Using TUNEL technique, it could correlate fine morphological changes with DNA fragmentation in apoptosis.

In this study apoptotic chromatin condensation occurred after 24 hours post inoculated. The result indicated that on control cells showed a clear cytoplasm, typical shape of nuclear membrane and centrally placed nucleus no cells exhibited any apoptosis feature (Figure 2A). At day 1 post-inoculated, early stage of apoptosis was observed. There was prominent nucleus condensation and increasing the cell density. It was clearly seen that there was convolution of nucleus membrane (Figure 2B) and starting of morphological appearance of fragmented nucleus (Figure 2C). Apoptosis process was continued by continuing of DNA strand-break process and beginning of the crecentric nucleus formation. DNA fragmentation were clearly seen and the cells membrane was blebbed which indicated that the formation of apoptotic bodies (2D).

In TUNEL assay, 3-OH DNA ends are enzymatically labeled with dUTP-fluorescein isothiocyanate (dUTP- FITC) using TdT and routinely used to monitor the DNA fragmentation associated with apoptosis in eukaryotes ${ }^{[16]}$. Although the exact pattern is different from cell type to cell type, in general the nucleus shrinks and its chromatin becomes condense, collapsing into patches, then into crescents in tight apposition to the nuclear envelope, and finally in many cells into one or several dense spheres. This change is often accompanied by fragmentation of the $\mathrm{DNA}^{[21]}$.

Surface morphological studies under scanning electron microscope (SEM) revealed the changes of apoptotic cells. At day 1 (Figure 3B) post-inoculation with neem leaves ethanolic extract, the HeLa cells showed smooth plasma membrane and only some cell showed early appearance of apoptosis that is indentation and/or blebbing of the cell surface. At day 2 (Figure 3C) post-inoculation, early stages of apoptosis appearance such as indentation and/or blebs on cell surface and hole on cell surface could be seen. Surface blebbing is considered a pattern specific of apoptosis. It is due to a deep cytoskeleton rearrangement, causing progressive changes in cell shape and organelle distribution ${ }^{[22]}$. At day 3 (Figure 3D) post-inoculation, cell disintegration was mostly noted and apoptotic bodies can be seen in this stage. The final stage of this process is the cell splitting in numerous portions, termed apoptotic bodies, whose common final fate in vivo is to be engulfed by macrophages ${ }^{[22]}$. Control (Figure 3A) cells showed smooth surface of plasma membrane.

Upon receiving specific signals instructing the cells to undergo apoptosis a number of distinctive biochemical and morphological changes occur in the cell ${ }^{[23]}$. The result of these biochemical changes is appearance of morphological changes in the cell[ ${ }^{[2]}$. Phagocytic cells are responsible for removing apoptotic cells from tissues in a clean and tidy fashion that avoids many of the problems associated with necrotic cell death. In order to promote their phagocytosis by macrophages, apoptotic cells often undergo plasma membrane changes that trigger the macrophage response. One such change is the translocation of phosphatidylserine from the inner leaflet of the cell to the outer surface. This and other alteration allows the early recognition and phagocytosis of apoptotic cells without release of proinflammatory mediators ${ }^{[22]}$.

Membrane changes can often be observed morphologically through the appearance of membrane blebs or indentations. Then a hole will form on the cell surface, indicating early step in the disintegration of the cell which often appear towards the end of the apoptotic 
process. The process is so efficient that dead cells disappear without leaving a trace, and inflammation is virtually absent.

Lesion scoring was done based on the appearance of apoptosis identified on the cell. Lesion scoring was done on surface morphology appearance and rated from 0 to 3 based on a certain criteria. Lesion scoring technique used in this study is based on the technique modified from Fauziah ${ }^{[25]}$ research. The result observed in this study suggests that the surface morpholological changes of cervical cancer cell lines was due to the ability and effectiveness of the neem leaves extract in inducing apoptosis. Table 1 showed the lesion score of treated HeLa cells and control group (with PBS). The changes of apoptosis were found to be duration-dependent. HeLa cell lines treated at 48 and 72 hours showed significant $(p<0.05)$ morphological changes when compared to control groups. While 24 hours treatment did not showed significant changes when compared to control groups. Nevertheless, the severity of the lesion is independent of the duration of the treatment given.

To observe the effectiveness of $A$. indica $\mathrm{EtOH}$ extracts in suppressing cancer causing genes / oncogenes, mRNA were extracted from the treated cells and untreated cells. The reverse transcription-polymerase chain reaction (RTPCR) was used. This is the most sensitive technique for mRNA detection and quantification. Also this method is simple for detecting gene expressions in a sample that it does not require expensive equipment, allows the rapid detection and measurement of many genes simultaneously by using nanogram amounts of complementary $\mathrm{DNA}^{[26,27]}$. Allowing the expression of oncogenes to be visualized clearly by an image analyzer. Different oncogenes have different temperatures for denaturizing, annealing, elongation and number of cycles to get the best PCR products.

The oncogenes expression was observed using three concentrations, a low, a medium dose which was an $\mathrm{IC}_{50}$ and a high concentration. The study showed that the c-myc genes expression (218 bp) was observed in untreated and treated (with EtOH extract of neem) on
HeLa cell lines. The housekeeping genes (15 s and $\beta$-actin) were expressed in both treated and untreated cells. Figure 4A shows that the level intensity of c-myc $(58.37,17.66,7.35 \mathrm{ng} / 1 \mu \mathrm{g})$ were significantly suppressed in HeLa cells after treating with 10,30 and $60 \mu \mathrm{g} / \mathrm{mL}$ A.indica EtOH crude extract. In treated cells, decreasing level of the c-myc oncogenes on the HeLa cells was down-regulated. This condition is as a response to sustaine DNA damage in the $\mathrm{HeLa}$ cell during DNA fragmentation in apoptosis.

This results were in parallel with previous studies where glucocorticoid-treated ${ }^{[28]}$ on CEM-7 (Human leukemic cells), 4Hydroxytamoxifen-treated on Myeloma cells ${ }^{[29]}$ and retinoic acid on lung cancer ${ }^{[30]}$. downregulated c-myc expression and caused the suppression or decreasing level of c-myc expression. On the other hand, there are many examples where c-myc is required, to a greater or lesser degree/level of expression for the efficient induction of apoptosis by a variety of stimuli $^{[31]}$. For example, in a variety of transformed cell types, c-myc antisense oligonucleotides cause growth inhibition, which in some (but not all) cases is associated with the onset of apoptosis ${ }^{[32]}$. The c-myc expressed might be due to the EtOH extract which gave the different stimuli in different cell types. Otherwise, under appropriate circumstance, both up and down regulation of c- myc can lead to apoptosis.

The concentration of 10,30 and $50 \mu \mathrm{g} / \mathrm{mL}$ on HeLa cells could not suppressed the level of cerb genes expression (Figure 4B) that the intensity of bands were $82.92,82.88,82.85$ $\mathrm{ng} / \mu \mathrm{g}$. In the treated cells, the expression of cerb was not down-regulated. This finding was consistent with previous investigations that pure antiestrogen (Faslodex) significantly upregulated c-erb expression which was featured the stable or increased level of c-erb genes expression $^{[33]}$. The expression of c-erb has been associated with differentiation and apoptosis process.

Otherwise the c-fos expression genes was decreasing along with increasing of $\mathrm{EtOH}$ extract concentration $(10,30$ and $50 \mu \mathrm{g} / \mathrm{mL})$ in treated HeLa cells (Figure 38) which the band's intensity were $32.36,24.62$ and 9.95 
$\mathrm{ng} / \mu \mathrm{g}$. The ethanolic extract of neem downregulated the c-fos expression in HeLa cells towards the decreased of c-fos level significantly (30 and $50 \mu \mathrm{g} / \mathrm{mL}$ ).

To undergo apoptosis the cells, are mediated by a complex integration of signal transduction pathways that include three groups of protooncogenic proteins. Decreased or increased of these oncogenes proteins is usually associated with the induction of apoptosis and affected by the cell-type specificity and the nature of the apoptotic stimuli such as drug or compounds. The genetic alterations of the different types of cells might affect ability to undergo apoptosis after extracellular stimuli. When oncogene activity was impaired after EtOH neem extract exposure, a severe induction of apoptosis occurred which suggested that the blocking of oncogene resulted in induction of apoptosis.

In other respects, there is certain oncogene stimulates another oncogene function undergo apoptosis. The c-fos and c-myc oncogene were correlated in apoptosis process. It has been identified that c-fos as a key player in c-mycmediated apoptosis for example, the upregulation of c-myc and c-fos oncogene were found in the human hepatoma cells undergone $\operatorname{apoptosis}^{[34]}$.

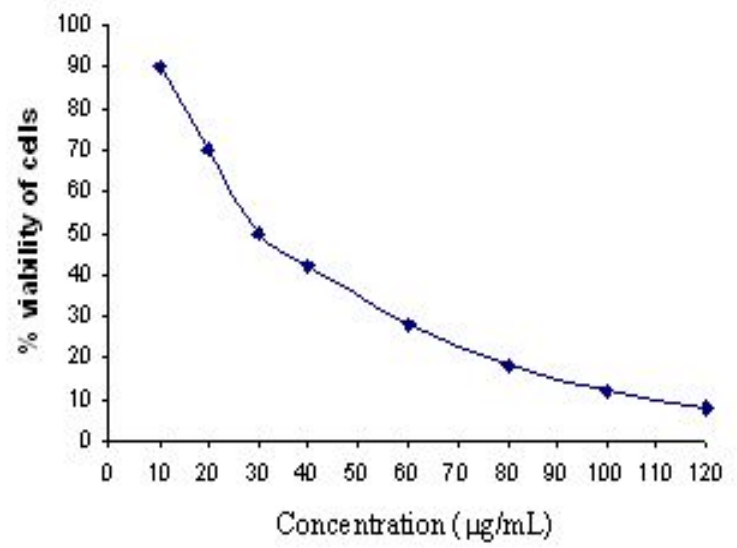

Figure 1. The effect of ethanolic extract of $A$. indica on HeLa cell lines. Cells were plated with $1 \times 10^{5}$ cells per well in 96-well culture plates. After 72 hours incubation at $37^{\circ} \mathrm{C}$, MTT assay was applied to assess cytotoxic effect. $\mathrm{IC}_{50}$ of 30.0 $\mu \mathrm{g} / \mathrm{mL}$ were obtained for HeLa. Data was expressed sixplicate \pm SD

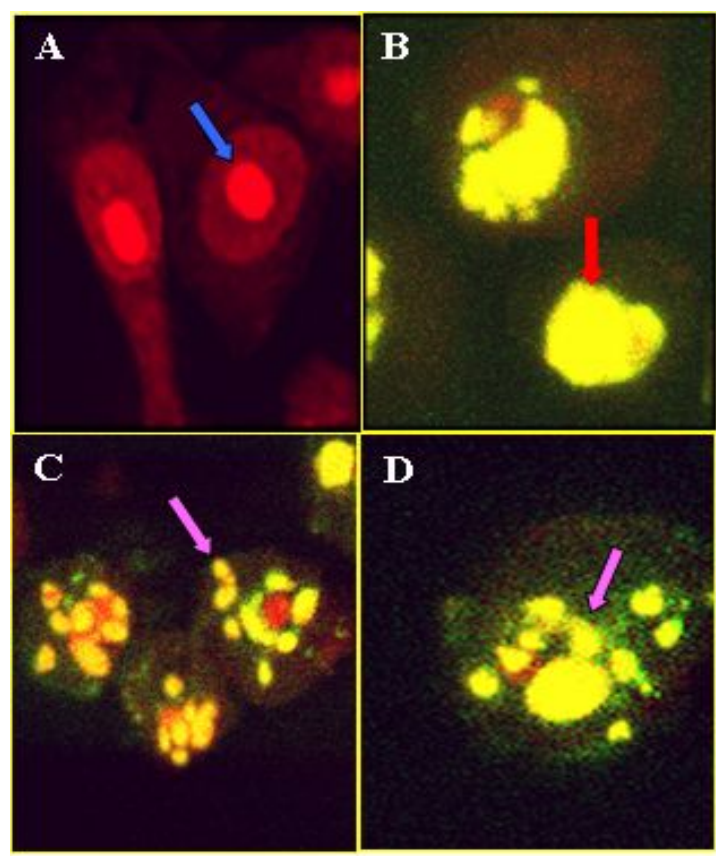

Figure 2. Confocal micrograph of MCF-7 cells, untreated cells (A), treated cells after exposed to ethanolic extract of $A$. India (neem) shows chromatin condensation (B), Initial morphological appearance of nucleus fragmentation (C), fragmented nucleus (D).
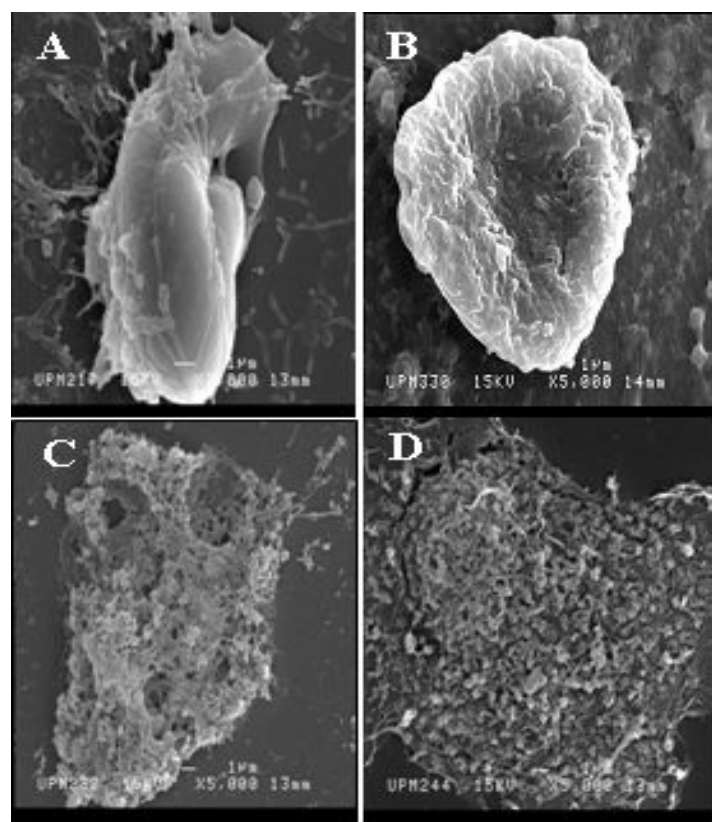

Figure 3. Scanning electron microscope micrographs of HeLa cells treated with neem leaves extract: (A) control showed smooth plasma membrane (B) treated at 24 hours showed indentations and blebs on the cell surface (C) treated at 48 hours showed hole on the cell surface and (D) treated at 72 hours showed disintegration of the cell. Mag. (A): x7000 

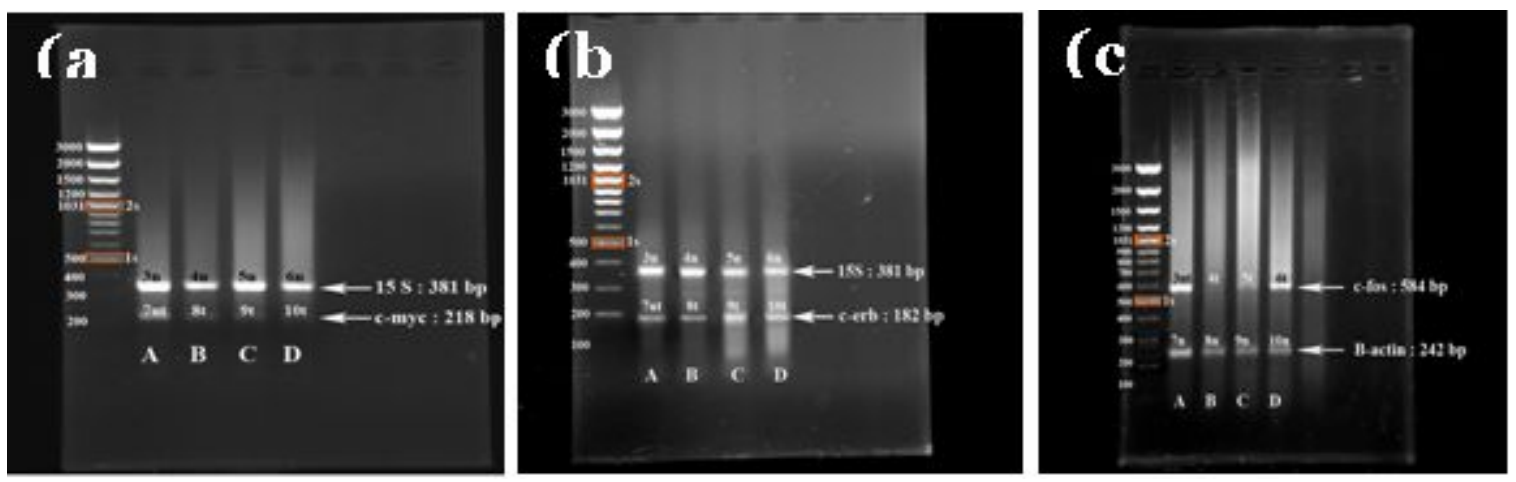

Figure 4. (a) Effect of EtOH extract of A.indica (neem) on the expression of c-myc gene in HeLa cell line. PCR products were analyzed on a 1.5\% agarose gel. M, 100 bp plus DNA ladder marker; lane 1, Heal control (untreated) ; lane 2, HeLa treated with $10 \mu \mathrm{g} / \mathrm{mL}$; lane 3, HeLa treated with $30 \mu \mathrm{g} / \mathrm{mL}$ and lane $4 \mathrm{HeLa}$ treated with $50 \mu \mathrm{g} / \mathrm{mL}$ EtOh extract of neem. (b) the expression of c-erb. Lane 1, HeLa control (untreated) ; lane 2 , HeLa treated with $10 \mu \mathrm{g} / \mathrm{mL}$; lane 3, HeLa treated with $30 \mu \mathrm{g} / \mathrm{mL}$ and lane $4 \mathrm{HeLa}$ treated with 50 $\mu \mathrm{g} / \mathrm{mL}$. (c) the expression of c-fos gene in HeLa cell lines. Lane 1, HeLa control (untreated) ; lane 2, HeLa treated with $50 \mu \mathrm{g} / \mathrm{mL}$; lane 3, HeLa treated with $30 \mu \mathrm{g} / \mathrm{mL}$ and lane $4 \mathrm{HeLa}$ treated with $10 \mu \mathrm{g} / \mathrm{mL} \mathrm{EtOH}$ extract of neem.

This finding suggested that ethanolic extract of neem intervene with the oncogene c-myc and c-fos in HeLa cells. However, the actual mechanism of up and down regulation of oncogenes involved in apoptosis mechanism is still investigated and needs further investigation to study deeply the mechanism up and down regulated of c-myc, c-erb and cfos before and after exposed to neem extract on these cells.

\section{ACKNOWLEDGMENT}

The authors would like to thank Associate Professor Dr. Rozita Rosli, Genetic and Molecular Biology labolatory and the staff of the Microscopy and Microanalysis unit, Institute of Bioscience, UPM for their contribution.

IRPA grant : 06-02-04-0597-EA 001

\section{REFERENCES}

1. Coarret, M. D., and Mittnacht, S., 2005, Oncogene and cell proliferation : The genetic and Biology of cancer revealing avenues for therapy, Current Opinion in Genetic and Development, 15: 1-4.

2. Anonymous, 2004, MAKNA: Majlis Kanser Nasional.

3. Shiva, 2001, Neem: A Plant for All season.
At: www.vshiva.net/naturefact $/$ neem $/ \mathrm{htm}$.

4. Schmutterer, H. S., 1995, Neem tree, Azadirachta indica A.Juss and other meliaceous plants, $\mathrm{VCH}$, weinheim, Germany.

5. Khosla, P., Bhanwara, S., Singh, S., Seth, S., and Srivastava, R. K., 2000, A study of hypoglycemic effect of Azadirachta indica in normal and alloxan diabetic rabbits, $J$. of Physiol. Pharmacol., 44 (1): 69-74.

6. Khan, P. K., Awasthy, K. S., 2003, Cytogenetic toxicity of neem, Food and Chemical Toxicology, 41: 1325-1328.

7. Krishnaveni, P., Ajantha, S., Narayani, M., Suherman, J., Susi Endrini, Asmah, R., Fauziah, O., 2002, Confocal microscopy on the effect of neem leaf extract on MCF7 breast cancer cell lines. Proc. Seminar Update on Microscopy and Microanal. UPM Press: Serdang, 48-49.

8. Fauziah, O., Fakurazi S., Asmah R., Ajantha, S., Krishnaveni, P., and Tengku Shahrul, T. M. Y., 2003, Azadirachta indica induces apoptosis in MCF-7 Breast cancer cells. Proceedings of the $12^{\text {th }}$ Scientific Conference and $13^{\text {th }}$ Annual General Meeting Electron Microscopy Society of Malaysia, Langkawi, Kedah, Malaysia, 512-516.

9. Wyllie, A. H., Kerr, J. F. R., and Currie, R., 1980, Cell death : The significance of apoptosis, Int. Rev. Cytol., 68: 251-306.

10. Steller, H., 1995, Mechanism and genes of 
ellular suicide, Science, 267: 1445-1449.

11. Yasuhara, S., Zhu, Y., Matsui, T., Tipirneni, N., Yasuhara, Y., Kaneki, M., Rosenzweig, A., Jeevendra, A.,, 2003, Comparison of Comet Assay, Electron Microscopy, and Flow Cytometry for Detection of Apoptosis, J. Histochem. Cytochem., 51: $873-885$.

12. Kelly, K. J., Sandoval, M. R., Dunn, K. W., Molitoris, B. A., and Dagher, P. C., 2003, A novel method to determine Specificity sensitivity of the TUNELreaction in the quantitation of apoptosis, Am. J. Physiol Cell Physiol, 284: 1309 - 1318.

13. Nasi, S., Ciarapica, R., Jucker, R., Rosati, J., and Soucek, L., 2003, Making decision trough c-myc, FEBS letter., 490: 153-162.

14. Suzanne, D. C., Kathrin, G., Eugene, S. K., Pratiratibha, K., Andrew, J., Wagner, Maura, O., and Nissim, H., 2000, Induction of Cell Cycle Progression and Acceleration of apoptosis are two separable functions of $c-m y c$ : Transrepression correlates with acceleration of apoptosis, Molecular and Cellular Biology, 20: 6008-6018.

15. Grooteclaes, M., Vernimmen, D., Plaza, S., Pasleu, F., Hodzie, D., and Winker, R., 1999, A new cis element is involved in the HER-2 gene overexpression in Human breast cancer cells, Cancer Research, 59: 2527-2531.

16. Cunni, M., Kramar, A., Courjal, F., Johannas, D., et al., 2000, Relating genotype and phenotype in breast cancer an analysis of the prognosis significance of amplification at eight different genes or loci and p53 mutation, Cancer Research, 60: 1077-1083.

17. Robert, A. H. and Alfred, N., 1999, In Vitro transcriptional analysis of the human c-fos proto-oncogene, The Journal of Biological Chemistry, $266: 19572-19582$.

18. Nurulaini, R., 2004, A study on the cytoskeletal proteins of breast cancer cell lines treated with Neem (Azadirachta indica) leaf extract, Final Year thesis, University Putra Malaysia.

19. Ajantha, S., 2000, Evaluation of apoptosis inducing ability of Neem (Azadirachta indica) leaf extract on MCF-7 breast cancer cell lines, Final Year thesis, University Putra Malaysia.

20. Lu, Z., Zhang, C., and Zhai, Z., 2005,
Nucleoplasmin regulates chromatin condensation during apoptosis, PNAS 102: 2778-2783.

21. Cohen, J. J., 1993, Overview : Mechanism of apoptosis, Immunology Today, 14: 126130.

22. Kumar, V., Ramzi S., Cotran, Stanley L., Robbins, 2003, Basic Pathology $7^{\text {th }}$ Edition. Saunders Elsevier Science, India.

23. McConkey, D. J., 1998, Biochemical determinants of apoptosis and necrosis, Toxicol. Lett., 99: 157-168.

24. Sluyser M., 1996, Apoptosis in Normal Development and Cancer, 2-86.

25. Fauziah, O., Purton, M. D., and Solomon, S. E., 1996, Scanning Electron Microscopy of the Respiratory Epithelium of Chicks Fumigated with Formaldehyde Vapour, British Poultry Science, 37: 563-570.

26. Willey, J. C., Crawford, E. L., Jackson, C. M., Weaver, D. A., Hoban, J. C., Khuder, S. A., and DeMuth, J. P., 1998, Expression measurement of many genes simultaneously by quantitative RT-PCR using standardized mixtures of competitive templates, American Journal Respiratory Cell Molecular Biology, 19: 6 - 17.

27. Loitsch, S. M., Kippenberger, S., Dauletbaev, N., Wagner, T. O., and Bargon, J., 1999, Reverse transcriptioncompetitive multiplex PCR improves quantification of mRNA in clinical samples-Application to the low abundance CFTR mRNA, Clinical Chemistry, 45: 619-624.

28. Ramachandran, T., Habour, D. V., and Thompson, E. B., 1993, Suppression of $c$ $m y c$ is a critical step in glucocorticoid induced human leukemia cell lysis, The Journal of Biological Chemistry, 28: $18306-18312$

29. Gauduchon, J., Gouilleux, F., Maillard, S., Marsaud, V., Renoir, J. M., and Brigitte, S. 2005, 4-Hydroxytamoxifen Inhibits Proliferation of Multiple Myeloma Cells In vitro through Down-Regulation of c-Myc, Up-Regulation of p27 Kip1, and Modulation of Bcl-2 Family Members, Clinical Cancer Research, 11: 2345 - 2354.

30. Hsu, S. H., Hsu, J. W., Liu, M. C., Chen, L. Y., and Chang C-D., 2000, Retinoic AcidMediated G1 Arrest Is Associated with Induction of $\mathrm{p} 27^{\mathrm{Kip} 1}$ and Inhibition of Cyclin-Dependent Kinase 3 in Human 
Lung Squamous Carcinoma CH27 Cells. Experimental Cell Research, 258: 322331.

31. Dong, J. M., Naito, Y., and Tsuruo, T., 1997, C-myc plays a role in cellular susceptibility to death receptor-mediated and chemotherapy-induced apoptosis in human monocytic leukemia U937, Oncogene, 15: 639-647.

32. Adachi, S., Obaya, A.J., Han, Z., Desmone, N.R., Wyche, J.H., and Sedivy, J.M., 2001, $\mathrm{C}$-myc is necessary for DNA damage induce apoptosis in G2 phase of the cell cycle. Molecular and cell Biology, 21: 4929 - 4937.

33. McClelland, R. A., Barrow, D., Tracie-
Ann, M., Dutkowski, C. M., Pamment, J., Knowlden, J.M., Gee, J.M.W., and Nicholson, R.I., 2001, Enhanced Epidermal Growth Factor Receptor Signaling in MCF7 Breast Cancer Cells after Long-Term Culture in the Presence of the Pure Antiestrogen ICI 182,780 (Faslodex), Endocrinology, 142: 27762789.

34. Kalra, N., and Kumar, V., 2004, C-fos Is a Mediator of the $c$-myc-induced Apoptotic Signaling in Serum-deprived hepatoma cells via the p38 mitogen-activated protein kinase pathway, Journal of Biological Chemistry, 279: 25313-25319. 
